\title{
SSynthesis
}

International Scientific Conference of IT and Business-Related Research

\section{OD TRADICIONALNOG KA ELEKTRONSKOM WORD-OF-MOUTH MARKETINGU}

\author{
FROM TRADITIONAL TO ELECTRONIC \\ WORD-OF-MOUTH MARKETING
}

\author{
Melita Jovanović Tončev, Marija Kostić, Vladimir Džamić \\ Univerzitet Singidunum, Danijelova 32, Beograd Srbija
}

\begin{abstract}
Apstrakt:
Dok oglašavanje (advertising), kao instrument promocionog miksa, predstavlja plaćenu komunikaciju između poznatog privrednog subjekta i potencijalnih korisnika, word-of-mouth marketing predstavlja pozitivnu ili negativnu ličnu komunikaciju koja ima za cilj da potpomogne navedenu interakciju u okviru definisane marketinške strategije kompanije. U radu će biti analizirana evolucija word of mouth marketinga od tradicionalnog ka elektronskom. Hronološki će se prikazati istraživanja koja su ukazala na značaj i mogućnosti ovog vida komunikacije. Posebno će biti analiziran period nakon devedesetih godina XX veka kada je pojava Interneta doprinela uspostavljanju neprekidne, dugotrajnije, sveobuhvatnije, transparentnije, dugoročno efikasne komunikacije, kako između samih potrošača, tako i između potrošača i kreatora marketinških aktivnosti.
\end{abstract}

\section{Ključne reči:}

word of mouth, tradicionalni word of mouth marketing, elektronski word of mouth marketing, preporuka prijatelja.

\section{UVOD}

Na uticaj i značaj usmene preporuke (word of mouth, WOM) na ponašanje potrošača prilikom odlučivanja o kupovini proizvoda ili usluge, naučnici su ukazivali preko 2400 godina (Buttle, 1998). Međutim, ozbiljnija istraživanja u ovoj oblasti su sprovedena tek posle Drugog svetskog rata. S obzirom da ne može da selektuje ogroman broj reklama i poruka kojima je okružen svakog dana (prema istraživanjima Privatnog instituta za Marketing i komunikacije čoveku se dnevno prezentuje više od 6000 poruka (Thinius, 2004), potrošač je sklon da uvažava preporuke prijatelja. Jedan od prvih istraživača uticaja WOM na ponašanje kupaca bio je Arndt. On je definisao WOM kao „usmenu, ličnu nekomercijalnu komunikaciju između pošiljaoca i komunikatora" (Arndt, 1967) koji nije samo primalac, već u sledećoj fazi procesa postaje i pošiljalac. American Word of Mouth Marketing Association (WOMMA) definiše WOM kao „interpersonalnu nekomercijalnu komunikaciju o brendovima, proizvodima ili uslugama i može biti pozitivna ili negativna" (WOMMA, 2008). Ono što je zajedničko ovim definicijama je da je reč o:

- nekomercijalnom prosleđivanju informacija,

- između potrošača,

- i da je sadržaj konverzacije evaluacija proizvoda ili usluga.

Pomenuta Asocijacija definiše WOMM (Word of Mouth Marketing) kao „davanje ljudima razloga da govore o proizvo-

\section{Abstract:}

Unlike advertising, which is an instrument of the promotional mix that represents paid communication between the known economic entity and potential users, word-of-mouth marketing is positive or negative personal communication aimed at promoting interaction within the defined marketing strategy of a company. The purpose of this paper is to analyze the evolution of word-of-mouth marketing from its traditional to electronic form. Several studies that have highlighted the importance and potentials of this type of communication will be presented in chronological order. Special attention will be devoted to the analysis of the period after the 1990s, which was marked by the emergence of the Internet that further contributed to establishing continuous, long-lasting, comprehensive, transparent, and long-term effective communication, both among consumers themselves and among consumers and creators of marketing activities.

\section{Key words:}

word of mouth, traditional word of mouth, electronic word of mouth, friends' recommendation.

dima i uslugama, kao i olakšavanje komunikacije. To je veština i nauka izgradnje aktivne i obostrano korisne potrošač-potrošač i potrošač-marketar komunikacije" (WOMMA, 2008). Dakle, WOMM nije konverzacija sama po sebi, već predstavlja generisanje i podsticanje komunikacija u okviru marketing strategija određene kompanije. (WOMMA, 2008; Sernovitz, 2007; Oetting, 2005). Ovo pojmovno određenje WOMMa je veoma bitno jer naglašava značaj usmeravanja komunikacije između potrošača pomoću različitih marketinških tehnika.

Tokom godina istraživači su razmatrali kako WOM zaista funkcioniše (Brooks, 1957; Dichter, 1966; Richins, 1983). Pojava Interneta, kao i omogućavanje brže, lakše, obuhvatnije komunikacije među potrošačima, navela je istraživače na analiziranje uticaja koje je on imao na promenu sadržaja i načina komunikacije među potrošačima (Dellacoras, 2003). Period krajem devedesetih godina XX veka i početak XXI veka može se smatrati renesansom WOM komunikacija, jer je Internet doprineo povećanju broja komunikacija među ljudima, kao i omogućio različite načine za deljenje sadržaja.

\section{TRADICIONALNI WORD-OF-MOUTH I MODEL EVOLUCIJE WORD-OF-MOUTH MARKETINGA}

Word-of-mouth komunikaciju još od ranih pedesetih godina XX veka istražuju i teoretičari i praktičari. Lična konverzacija i neformalna razmena informacija između prijatelja, rođaka, 
saradnika, poznanika, nije samo imala uticaja na odluke o kupovini (Arndt, 1967), već je oblikovala i očekivanja potrošača (Anderson \& Salisbury, 2003), formirala stavove pre kupovine (Herr et al. 1991), kao i (ne)zadovoljstvo nakon upotrebe proizvoda ili korišćenja usluga (Bon, 1995).

Bez obzira na mnoštvo literature koja je tokom godina istraživala ovu oblast, smatra se da se veoma malo zna kako WOM zaista funkcioniše i šta je to što motiviše potrošača da dalje prosleđuje svoje stavove i iskustva u vezi određenog brenda, kompanije, proizvoda ili usluge (De Bruyan, 2008). Najpre, to je iz razloga što su se mnogi istraživači fokusirali na uspešne WOM komunikacije, odnosno na one koje su uticale na proces donošenja odluke potrošača o kupovini. Zatim, zbog toga što su mnoga istraživanja ispitivala komunikacije primalaca koji su aktivno tražili informacije o kompaniji, proizvodima ili uslugama. U mnogim istraživanjima, podaci su prikupljani retroaktivno, ponekad mesecima ili godinama nakon što je komunikacija uspostavljena (Wangen \& Bayón, 2004). Na kraju, mnoga istraživanja su merila uticaj WOM-a tako što su prikazivani podaci o kupcima koji su se odlučili na kupovinu, dok je zanemaren procenat kupaca koji su se opredelili na kupovinu proizvoda pod uticajem nekog drugog instrumenta marketinga.

U svim pomenutim istraživanjima je naglašeno da proizvod mora biti interesantan kako bi se o njemu govorilo. Sernovitz (2006) ističe da je veoma važan princip WOMM-a intrigantnost, jer niko ne govori o dosadnim kompanijama, proizvodima ili uslugama.

Pojava Interneta, njegove mogućnosti, dostupnost, sveobuhvatnost i transparentnost uslovili su promene u ponašanju potrošača prilikom razmene informacija i stavova o određenim brendovima i proizvodima. Izmenjen je način na koji oni komuniciraju, prenose ideje i mišljenje, kao i način na koji nosioci marketing aktivnosti utiču na tok komunikacija. Nova marketinška realnost iziskivala je i novi okvir upravljanja WOM-om, odnosno promene na tržištu su promenile i teoriju marketinga. Dok su potrošači ranije želeli da razmene informacije kako bi pomogli jedni drugima prilikom odlučivanja o kupovini, deljenje informacija u digitalnom okruženju se skoro podrazumeva. Na slici 1 je prikazana evolucija WOM teorije.

A: Organski međuholistički model uticaja
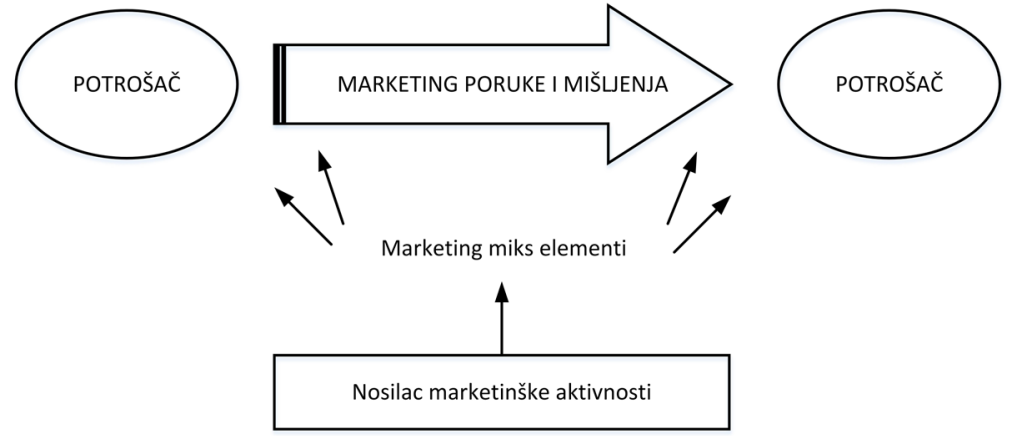

B: Linearni model uticaja marketinških subjekata
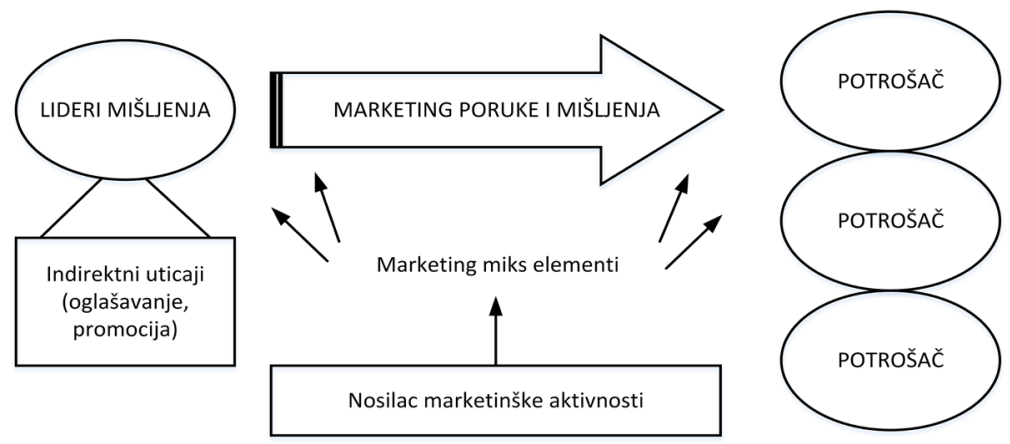

C: Mrežni saradnički model

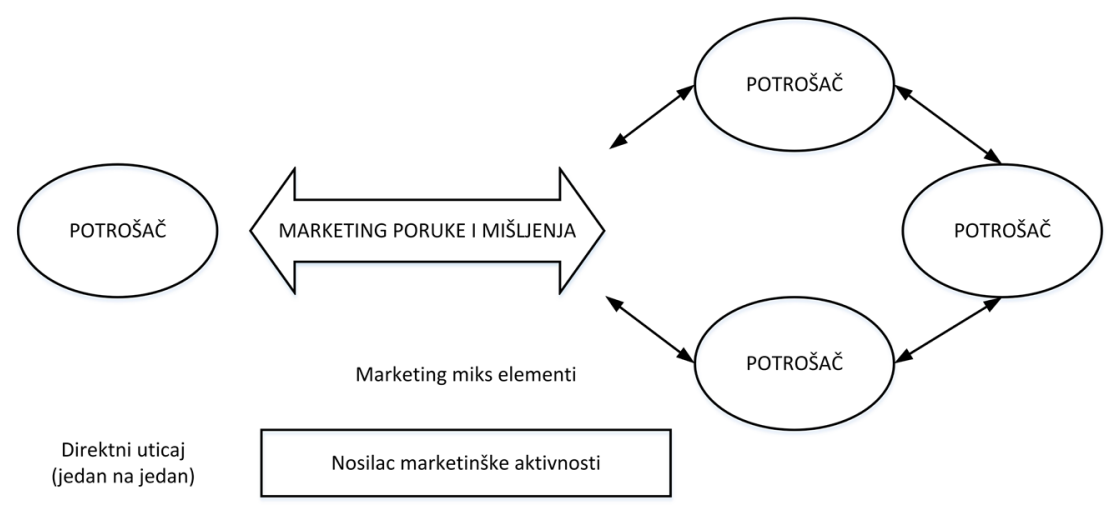


1. Istraživači tradicionalnog WOM-a (Ryan \& Gross, 1943) su smatrali da je konverzacija između potrošača mnogo važnija od marketing komunikacija. Ovo je model koji je na slici br. 1 obeležen slovom A i nosi naziv organski model. Ovaj naziv je dobio jer potrošač komunicira bez direktnog uticaja ili merenja efekata komunikacija od strane nosilaca marketing aktivnosti. Širenje informacija motivisano je željom da se pomogne drugima, odnosno da se upozore potrošači na lošu uslugu.

2. Kako se dalje razvijala teorija o WOMM-u, počela je da se uviđa važnost lidera u prenošenju informacija (King \& Summers, 1976). Interes kreatora marketing aktivnosti je da utiču na potrošače koji imaju kredibilitet među potencijalnim korisnicima. Ovo shvatanje je doprinelo da se integriše nova teorija o aktivnom učešću marketinških stručnjaka putem tradicionalnih sredstava promocije (oglašavanja) na lidere, kako bi postali prenosioci informacija i uticali na formiranje pozitivnog stava o kompaniji, brendu, proizvodu ili usluzi.

3. Sledeća faza u razvoju WOMM-a se može nazvati njegovom renesansom. Pojava i primena Interneta omogućila je s jedne strane, potrošačima nove načine komuniciranja i razmene mišljenja, dok je s druge strane, kompanijama olakšala upravljanje WOM aktivnostima i ponudila nove tehnike merenja uspešnosti ovog vida marketinga. Novi model, nazvan, mrežni saradnički model, prikazao je nove odnose koji su uspostavljeni između potrošača, kao i aktivnu ulogu koju korisnici preuzimaju u ovoj interakciji. Formiranjem grupa i virtuelnih zajednica, potrošači postaju saradnici u stvaranju vrednosti i mišljenja o kompaniji.

\section{ELEKTRONSKI WOM}

Pojava Interneta, kao i svakodnevno proširivanje mogućnosti koje nudi korisnicima, uslovili su da se period nakon devedestih godina XX veka može smatrati značajnim koliko i period industrijske revolucije (Choi \& Scott, 2013). Internet je postao osnovni medij informisanja i komuniciranja. Paradigma Interneta je promenjena upotrebom Veb 2.0 koji je svojim korisnicima ponudio nove poslovne mogućnosti, ka upravljanje na osnovu znanja. Najviše korišćene usluge Veb 2.0 su društvene mreže putem kojih učesnici komunikacije kreiraju sopstveni profil i stvaraju linkove (povezuju se) sa ostalim članovima (Boyd \& Ellison, 2008).

Elektronski WOM je razmena mišljenja između potrošača o iskustvu (1) u kojoj lideri mišljenja imaju vodeću ulogu u procesu razmene informacija (2). Interakcija se odvija putem Internetaonline platformi (3), koje su orijentisane (4) i usmerene ka mnoštvu ljudi (5). Elektronski WOM je interakcija bez vremenskog i prostornog ograničenja (6) i može biti anonimna (7). Zahvaljujući online okruženju, moguće je proveriti kredibilitet učesnika komunikacije (8). U svakom slučaju, eWOM je itekako prisutna tokom potrošačevog procesa donošenja odluka o kupovini (9). Brojevima su naznačene osnovne karakteristike eWOMa.

Razvoj Veb 2.0 (takozvanog interaktivnog veba (Eck, 2007)), ponudio je potrošačima mnoštvo novih mogućnosti putem kojih je moguće ostvariti komunikaciju (blogovi, vlogovi, portal, forumi, wikisi, društvene mreže). Najveći stepen primene u dosadašnjoj marketinškoj praksi imaju blogovi, wikisi i društvene mreže (Sudarević, 2013).

Blogovi su jedan od oblika lične veb-stranice, sa čestim promenama sadržaja, na kojoj pojedinac postavlja informacije o sebi ili o temi koja je predmet njegovog interesovanja (Baker \& Moore, 2008). To su veb-stranice na kojima autori komentarišu određene oblasti u obliku teksta ili multimedijalnih sadržaja. Neograničena mogućnost komentarisanja predstavlja važnu osobinu ove kategorije Veb 2.0 aplikacije koja time postaje sastavni deo upravljanja sistemima znanja (Sudarević, 2013).

Wikisi su veoma slični blogovima i predstavljaju niz veb stranica na kojima se komentariše određena tema. Ovim stranicama je lako pristupiti i postati aktivni učesnik kreiranja sadržaja. Ono što odlikuje wikise je lakoća upotrebe, otvorenost i fleksibilnost, ali im se upravo iz pomenutih razloga može zameriti velika izloženost vandalizmu zlonamernih i malicioznosti neupućenih osoba (Bogatin, 2006).

Društvene mreže su u svom začetku omogućavale postavljanje multimedijalnih sadržaja od strane pojedinaca koji su bili dostupni velikom broju korisnika (kao što je danas Yuotube). Sledeću fazu razvoja društvenih mreža karakteriše pojava Facebook-a, MySpace, Twitter-a i LinkedIn-a. Prema podacima sa Facebook-ovog sajta postoji 750 miliona aktivnih članova koji razmenjuju informacije u okviru ove mreže, dok su članovi LinkedIna korisnici koji su povezani na osnovu zanimanja kojim se bave, tako da se putem ove mreže prenose informacije u poslovnom marketingu.

Nedostatke i limitiranost tradicionalnog WOM uspeo je da nadomesti Internet, kao multimedijalno sredstvo komunikacije. Omogućavajući interaktivnost među korisnicima obezbedio je i neprekidnu komunikaciju, lakši pristup informacijama, ažurirane informacije, sveobuhvatnost, mogućnosti targetiranja specifično određenih ciljnih grupa potrošača (Sankatsing, 2007).

\section{SLIČNOSTI I RAZLIKE IZMEĐU TRADICIONALNOG I ELEKTRONSKOG WOM-A}

Uprkos stavovima mnogih naučnika da eWOM predstavlja nastavak tradicionalnog, ali putem elektronskih medija (Strutton et al., 2011; Yeh \& Choi, 2011) potrebno je ukazati na razlike i nove mogućnosti koje postoje u eWOM-u. Anonimnost, neprekidna konverzacija, veliki domet, broj osoba koje komuniciraju, dugotrajnost efekata takve komunikacije, medij putem koga se uspostavlja komunikacija, broj izvršenih interakcija su osnovne razlike između tradicionalnog i elektronskog WOM-a.

Dok se interakcija u okviru tradicionalnog WOM-a uspostavlja između pripadnika određene društvene zajednice (rođaka, prijatelja, poznanika, poslovnih saradnika), u eWOM-u komunicira se putem društvenih mreža i između članova korisnika određenih mreža.

Zajednička karakteristika tradicionalnog i eWOM je cilj deljenja informacija. Reč je o nekomercijalnoj motivisanosti sa željom da se razmene iskustva i stavovi o proizvodima, brendu, kompanijama ili uslugama.

Potrošači u eWOM-u mogu komunicirati putem različitih sredstava. Informacije se ne moraju razmenjivati isključivo posredstvom kompjutera, već korisnici mogu deliti svoja očekivanja, stavove, iskustva, posledice kupovina i putem mobilnih telefona (Okazaki, 2009). Koncept funkcionisanja Interneta i njegova multimedijalnost uslovljavaju i osnovne razlike između tradicionalnog i eWOM-a. Neprekidna dostupnost, ažuriranost, veoma lak pristup informacijama, globalna pokrivenost, neograničen broj izvora informacija o proizvodima olakšavaju potencijalnim korisnicima razmenu informacija. Veoma često potrošači koji žele da podele informaciju snimaju video material, fotografije ili prezentacije o proizvodima i na taj način postaju aktivni učesnici u oblikovanju internet sadržaja. Navedene osobine Interneta su doprinele da on u značajnoj meri utiče na odluku potrošača o kupovini (Brown et al., 2007). 

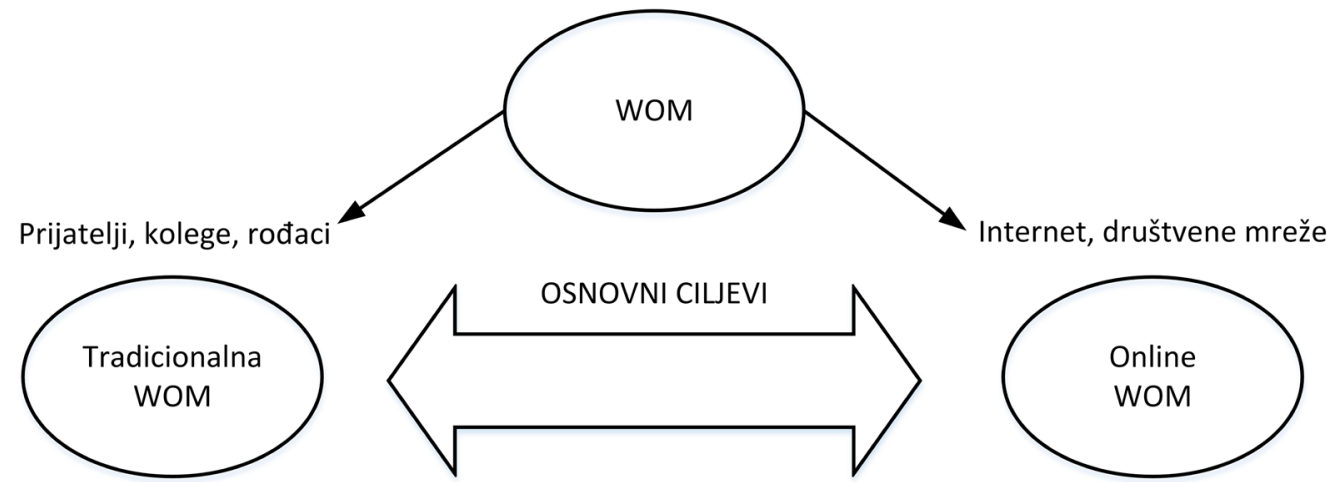

NEKOMERCIJALNA MOTIVISANOST

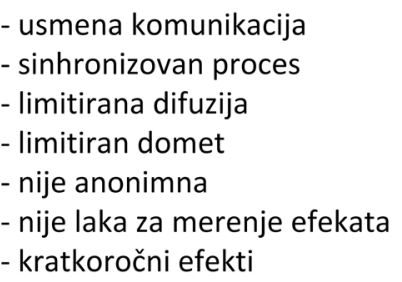

Slika 2. Sličnosti i razlike između tradicionalnog i elektronskog WOMa Prilagođeno prema: Gferer \& Pokrywka (2012)

Broj interakcija koje se mogu obaviti online je neuporedivo veći od broja razmene informacija u offline situacijama, kao i veliki broj učesnika u svakoj komunikaciji. Proces razmene informacija je mnogo brži, efekat dugotrajniji, a rezultati posledice ostaju i mnogo godina nakon izvršene interakcije. Negativni eWOM u vezi neke greške određene kompanije u 2003. godini će biti vidljiv korisniku koji pretražuje podatke o datoj kompaniji i 2014. godine. Sa druge strane, pozitivni eWOM će koristiti kompaniji tokom dugog niza godina, jer su mišljenja korisnika na digitalnim sredstvima komunikacije dostupna dugoročno i svima.

\section{ZAKLJUČAK}

Tradicionalne, kao i elektronske WOM komunikacije predstavljaju veoma važan način prenošenja informacija o stavovima, očekivanjima, iskustvima o proizvodu između potrošača. To je snaga koju bi WOMM trebalo da iskoristi kako bi se ostvarili ciljevi kompanija, kao što su zadovoljenje potreba potrošača uz ostvarenje profita, vodeći računa o društvenoj odgovornosti kompanije, kao i o uspostavljanju dugotrajnih odnosa sa potrošačima.

\section{LITERATURA}

Anderson, E. W., \& Salisbury, L. C. (2003). The formation of market-level expectations and its covariates. Journal of Consumer Research, 30, 115-124.

Arndt, J. (1967). Role of product-related conversations in the diffusion of a new product. Journal of Marketing Research, 4, 291-295.

Baker, J., \& Moore, S. (2008). Distress, Coping and Blogging: Comparing New MySpace Users by their Intention to Blog. Cyberpsychology \& Behaviour, 11(1), 81-85. DOI:10.1089/ cpb.2007.9930.

Bogatin, D. (2006). Why Digg fraud, Google bombing, Wikipedia vandalism will not be stopped, 12.12.2014, Dostupno na www.zdnet.com/blog/micro-markets/why-digg-fraudgoogle-bombing-wikipedia-vandalism-will-not-bestopped $/ 420$

Boyd, D. M., \& Ellison, N. B. (2008). Social network sites: Definition, history and scholarship. Journal of Computer Mediated Communication, 13(1), 210-230.

Brooks, R. C. (1957). Word of Mouth Advertising in Selling New Products. The Journal of Marketing, 22 (2), 154-161.

Brown, J., Broderick, A. J., \& Lee, N. (2007). Word of Mouth Communication within online communities: conceptualizing the online social network. Journal of Interactive Marketing, 21(3), 2-20.

Buttle, F. (1998). Word of mouth: understanding and managing referral marketing. Journal of Strategic Marketing, 6, 241-254.

Choi, J. H., \& Scott, J. E. (2013). Electronic Word of Mouth and Knowledge sharing on Social Network Sites: A Social Capital Perspective. Journal of theoretical and applied electronic commerce research, 8(1), 69-82. DOI: 10.4067/SO71818762010000300001.

De Bruyan, A., \& Lilien, G. L. (2008). A multi-stage model of word-of-mouth influence through viral marketing. International Journal of Research in Marketing, 25, 151-163.

Dellacoras, C. (2003). The Digitalization of word of mouth: Promise and Challenges of Online Feedback Mechanisms. Management Science, 49(10), 1407-1424.

Dichter, E. (1966). How word-of-mouth advertising works. Harvard Business Review, 44(6), 147-160.

Gferer, A., \& Pokrywka, J. (2012). Traditional versus Electronic Word-of-mouth, Lund University.

Eck, K. (2007). Corporate Blogs: Unternehmen im Online Dialog zum Kunden. Zurich: Orell Fussli Verlag.

Egli, A., \& Gremaud, T. (2008). Die Kundenrevolution: Warum Unternehmen undenken mussen. Stuttgart: Schaeffer-Poeschel.

Herr, P.M., Kardes, F.R. \& Kim, J. (1991). Effects of word-ofmouth and product attribute information on persuasion: An accessibility-diagnosticity perspective. Journal of Consumer Research, 17(4), 454-462. 
Kozinets, R.V., de Valck, K., Wojnicki, A.C., \& Wilner, S.J.S. (2010). Networked Narratives: Understanding Word of Mouth Marketing in Online Communities. Journal of Marketing, 74, 71-89.

Kotler, P., \& Armstrong, G. (2013). Marketing. Prentice Hall. Pearson: New Jersey

Meiners, N.H., Schwarting, U., \& Seeberg, B. (2013). The Renaissance of Word-of-Mouth Marketing: A new standard in Twenty-First Century Marketing Management. International Journal of Economic Science and Applied Research, 3(2), 79-97.

Oetting, M. (2005). Was ist Word of Mouth Marketing (Mundpropaganda Marketing)? 27.12.2014. Dostupno na www. connectedmarketing.de/cm/2005/04/was-ist-word-of.html

Okazaki, S. (2009). Social influence model and electronic Word of mouth, International Journal of Advertising, 28(3), 439-472.

Richins, M.L. (1983). Negative Word-of-mouth by Dissatisfied Consumers: A Pilot Study. Journal of Marketing, 47(1), 68-78.

Sankatsing, Y. (2007). Implications of media fragmentation for the advertising industry with special attention to the Philips account strategy of DDB.

Sernovitz, A. (2006). Word of Mouth Marketing: How Smart Companies Get People Talking. Chicago: Kaplan Publishing
Sernovitz, A. (2007). Is viral marketing the same as word of mouth, 10.12.2014. Dostupno na www.damniwish.com/2007/10/isviral-market.html

Strutton, D., Taylor. D.G. \& Thompson, K. (2011). Investigating generational differences in eWOm behaviours. International Journal of Advertising, 30(4), 559-586.

Sudarević, T. (2011). Viralni marketing u sklopu web 2.0 marketing strategije. U: Novi metodi menadžmenta i marketinga u podizanju konkurentnosti srpske privrede. Centar za izdavačku delatnost Ekonomskog fakulteta: Beograd.

Thinius, M. (2004). Mehr als 6000 Werbekontakte pro Tag sollen wir wahrnehmen-die aktuelle IMK-studie, 12.12.2014. Dostupno na www.presseportal.de/meldung/586040

v. Wangenheim, F., \& Bayón, T. (2004). The Effect of Word-ofMouth on Services Switching: Measurement and Moderating Variables. European Journal of Marketing, 38(9/19), 1173-1185.

Yeh, Y.H., \& Choi, S. M. (2011). Mini lovers, maxi-mouths: An investigation of antecedents to eWOM intention among brand community members. Journal of Marketing Communications, 17(3), 145-162. 